\title{
BMJ
}

\section{Fruit and vegetable intake and incidence of type 2 diabetes mellitus: systematic review and meta-analysis}

\author{
Patrice Carter, research nutritionist, ${ }^{1}$ Laura J Gray, research associate in medical statistics, ${ }^{2}$ Jacqui Troughton, \\ senior research associate, ${ }^{3}$ Kamlesh Khunti, professor of primary care diabetes and vascular medicine, ${ }^{2}$ \\ Melanie J Davies, professor of diabetes medicine ${ }^{1}$
}

${ }^{1}$ Diabetes Research, Department of Cardiovascular Sciences, University of Leicester, Leicester LE1 5WW

${ }^{2}$ Clinical Division of General Practice and Primary Health Sciences, University of Leicester, Leicester LE1 7RH

${ }^{3}$ Diabetes Research Department, University Hospitals of Leicester NHS Trust, Leicester Royal Infirmary, Leicester LE1 5WW

Correspondence to: $\mathrm{P}$ Carter, University of Leicester, Diabetes Research Team, Level 6, Windsor Building, Leicester Royal Infirmary, Leicester LE15WW pc154@le.ac.uk

Cite this as: $B M J$ 2010;341:C4229 doi:10.1136/bmi.c4229

\section{ABSTRACT}

Objective To investigate the independent effects of intake of fruit and vegetables on incidence of type 2 diabetes. Design Systematic review and meta-analysis.

Data sources Medline, Embase, CINAHL, British Nursing Index (BNI), and the Cochrane library were searched for medical subject headings and keywords on diabetes, prediabetes, fruit, and vegetables. Expert opinions were sought and reference lists of relevant articles checked. Study selection Prospective cohort studies with an independent measure of intake of fruit, vegetables, or fruit and vegetables and data on incidence of type 2 diabetes.

Results Six studies met the inclusion criteria; four of these studies also provided separate information on the consumption of green leafy vegetables. Summary estimates showed that greater intake of green leafy vegetables was associated with a $14 \%$ (hazard ratio 0.86 , $95 \%$ confidence interval 0.77 to 0.97 ) reduction in risk of type 2 diabetes $(\mathrm{P}=0.01)$. The summary estimates showed no significant benefits of increasing the consumption of vegetables, fruit, or fruit and vegetables combined. Conclusion Increasing daily intake of green leafy vegetables could significantly reduce the risk of type 2 diabetes and should be investigated further.

\section{INTRODUCTION}

The prevalence of diabetes is currently estimated to be about $6.4 \%$ worldwide,${ }^{1}$ and in the past two decades alone there has been a dramatic increase in the diagnosis of type 2 diabetes. ${ }^{1}$ Dietary factors are important and are potentially modifiable risk factors. There has been a focus on the role of carbohydrates and fibre, ${ }^{23}$ but the relation between fruit and vegetable intake and incidence of type 2 diabetes is not fully understood. A recent meta-analysis concluded that there is overwhelming support for the benefit of lifestyle interventions to prevent type 2 diabetes. ${ }^{4}$ Several of these intervention studies have included the promotion of fruit and vegetables in the diet. ${ }^{5-8}$ Low consumption of fruit and vegetables, however, is common throughout the world. ${ }^{9}$ In 2002 the National Diet and Nutrition Survey showed that $86 \%$ of all men and women in the United Kingdom consumed less than the recommended five portions of fruit and vegetables a day, with $62 \%$ consuming less than three portions. ${ }^{10}$ It was estimated that inadequate consumption of fruit and vegetables could have accounted for 2.6 million deaths worldwide in the year 2000. ${ }^{11}$

High intake of fruit and vegetables has been associated with a reduced incidence of cancer and cardiovascular disease. ${ }^{12}{ }^{13}$ Diabetes is a strong independent risk factor for cardiovascular disease,${ }^{14}$ and often the conditions exist together, sharing common modifiable risk factors. ${ }^{15}$ As yet no firm conclusions have been made as to whether increasing intake of fruit and vegetables can decrease the risk of type 2 diabetes itself, given the abundance of conflicting evidence within the literature. The exact mechanisms by which fruit and vegetables reduce the risk of these chronic diseases are not precisely known. A combination of antioxidants and phytochemicals found in fruit and vegetables might promote health by combating free radicals, which are linked with early phase development of some chronic diseases. ${ }^{16}$ High intakes of fruit and vegetables have been shown to increase concentration of plasma carotenoids and vitamin $\mathrm{C},{ }^{17}{ }^{18}$ both of which have antioxidant properties. An increase in fruit and vegetables in the diet of people with type 2 diabetes can also lower markers of oxidative stress. ${ }^{19}$

A previous review in 2007 concluded that consumption of three or more servings of fruit and vegetables a day was not associated with a substantial reduction in the risk of type 2 diabetes. ${ }^{20}$ This review was restricted by language and searched only a small number of electronic databases. In addition, recent studies have been published that could further contribute to the pooled data and allow further investigation into any association.

\section{METHODS}

\section{Search strategy}

In consultation with the research team we used the Cochrane handbook ${ }^{21}$ and the guide to systematic reviews from the Centre for Reviews and Dissemination ${ }^{22}$ to develop a systematic review protocol. To ensure a broad search, the search strategy included the medical subject headings (type 2 diabetes, 


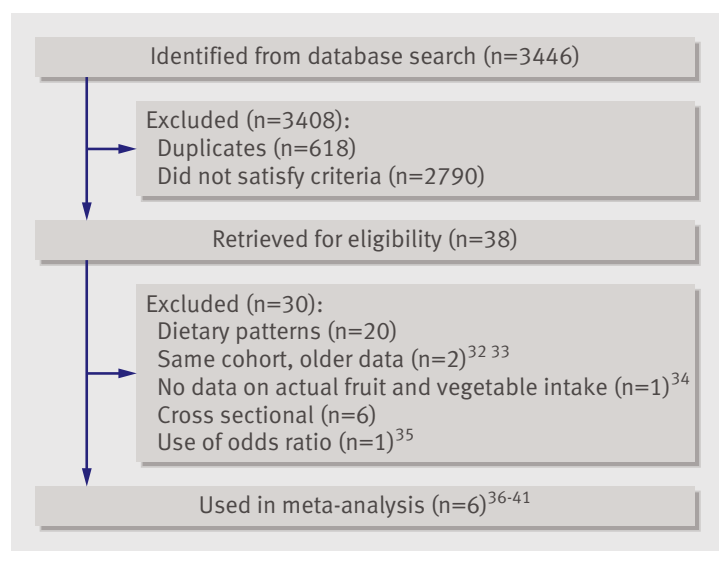

Fig 1 Process of study selection

prediabetes, impaired glucose tolerance, impaired fasting glucose, fruits, vegetables, citrus, follow-up, and prospective studies). Text word, title word, abstract, and subject headings were also searched for the above terms plus several non-medical subject headings to cover fruit, vegetables, and diabetes.

We searched OVID Medline(R), in process and other non-indexed citations, and OVID Medline(R), 1950 to February 2009; Embase, 1980 to March 2009; the Cumulative Index to Nursing and Allied Health Literature (CINAHL) and the British Nursing Index (BNI), from inception (1981 and 1985, respectively) until March 2009, via NLH Search 2.0; and three databases in the Cochrane Library (CDSR, CENTRAL, DARE) from inception to issue 1, 2009.

We sought expert opinion and checked references in any articles that met the inclusion criteria. There were no language restrictions.

\section{Study selection}

To be included, studies had to be prospective cohort studies that included an individual measure of intake of fruits, vegetables, or fruit and vegetable and an assessment of the development of type 2 diabetes. One reviewer $(\mathrm{PC})$ performed the search and reviewed the results. Studies that did not meet the inclusion criteria were discarded during the initial review. When uncertainty existed we retrieved and assessed the full text article. Two reviewers (PC and JT) independently assessed all potentially relevant studies and resolved any uncertainty through discussion. No relevant papers were found in languages other than English.

\section{Validity assessment}

Two authors (PC and JT) independently assessed all studies for quality. A scoring system was created to account for participants ( 1 point if any justification was given for the cohort and 1 point for appropriate inclusion and exclusion criteria), outcome (1 point if diagnosis of type 2 diabetes was confirmed according to accepted clinical criteria ${ }^{2324}$ and not based on self report), intervention (1 point if participants' usual fruit and vegetable consumption was assessed with a validated tool ${ }^{25}$ ), and statistical analysis (1 point was given if adjustments were made for age, body mass index (BMI) and family history of type 2 diabetes, these being proven risk factors for type 2 diabetes). Another point was given for any other adjustments, such as physical activity.

The system was designed with reference to MOOSE, ${ }^{26}$ QUATSO,${ }^{27}$ and STROBE ${ }^{28}$ and allowed a total score from 0 to 6 points, with 6 reflecting the highest quality.

\section{Data abstraction and synthesis}

Two authors (PC and JT) independently extracted data on the diagnosis of type 2 diabetes, intake of fruit and vegetables, and the associated risk. Hazard ratios and relative risks were used as a measure of the association. We assumed relative risks to be a valid approximation of hazard ratio, ${ }^{21}$ enabling the use of one consistent measure. The studies used various measurements for intake-for example, servings per week, grams per day. We standardised all data into servings per day, using a standard portion size of $106 \mathrm{~g} .{ }^{29}$ Any disagreement was resolved through discussion. When insufficient data were published we contacted authors.

\section{Statistical methods}

We transformed hazard ratios and relative risks by taking their natural logarithms and calculating standard errors and corresponding confidence intervals. ${ }^{30}$ Hazard ratios and their standard errors were pooled with a random effects model to account for statistical heterogeneity between studies to calculate summary hazard ratios and $95 \%$ confidence intervals for the highest versus lowest level of consumption. ${ }^{31}$ The data were analysed with Stata (version 10). Heterogeneity was assessed with the $\mathrm{I}^{2}$ statistic. We carried out subgroup analyses based on the quality of the study (high quality (4-6) $v$ lower quality $(<4)$ ), sex (men and women included $v$ women only), length of follow-up $(<$ 10 years $v \geq 10$ years), fractions of intake (comparison of the different quantification of intake, either thirds, quarters, or fifths), and location (United States and Europe $v$ China) as these were thought to be possible sources of heterogeneity. Significance was set at $\mathrm{P}<0.05$ and $95 \%$ confidence intervals are quoted throughout.

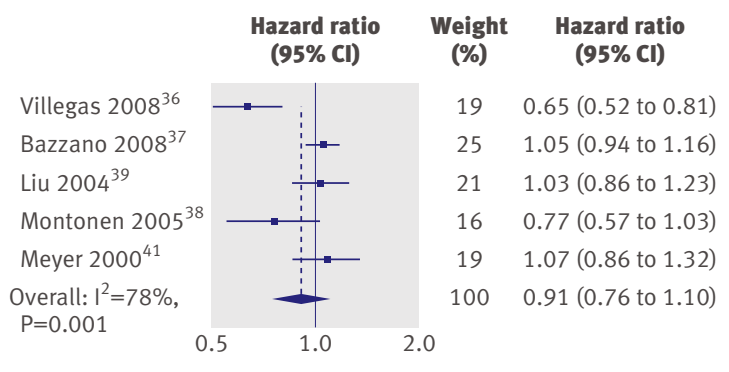

Fig 2 | Hazard ratios for incidence in diabetes type 2 for highest versus lowest intake of vegetables. Weights are from random effects analysis 


\section{RESULTS}

The search identified 3446 articles (fig 1). We assessed titles and abstracts and obtained full articles of potentially relevant studies. Several articles examined fruit and vegetable intake within a dietary pattern only or were cross sectional in design and therefore could not be included. In two cases papers reported data from the same study so we excluded the older papers. ${ }^{32} 33$ One study did not give enough details on actual fruit and vegetable intake to warrant inclusion within the metaanalysis. ${ }^{34}$ Another study was excluded as data were presented as odds ratios, ${ }^{35}$ and the combination of odds ratios and relative risks can lead to misinterpretation of results. ${ }^{21} \mathrm{We}$ added data from that study in the sensitivity analysis to see if it significantly altered the observed associations.

\section{Study characteristics}

Six studies met all the inclusion criteria. ${ }^{36-41}$ Table 1 shows the study characteristics and main outcomes. The combined population resulted in 223512 study participants; only two studies included men. ${ }^{3840}$ The age of participants ranged from 30 to 74 years. Study length ranged from 4.6 years to 23 years (median of 13 . 4 years). Three papers provided information on fruit and vegetable intake separately and combined. ${ }^{373941}$ Two papers provided information on fruit and vegetable intake separately, ${ }^{3638}$ and another paper provided only the combined data. ${ }^{40}$ Four papers also included separate data on the intake of green leafy vegetables. ${ }^{36-39}$ In most papers intake of fruit and vegetables was divided into fifths, though the paper by Ford and Mokdad analysed the data as thirds ${ }^{40}$ and the paper by Montonen and colleagues examined quarters. ${ }^{38}$

\section{Study quality and publication bias}

None of the papers met all of the criteria of the quality assessment tool, with all papers missing out on a point for justification of the cohort. Papers did not state that a power calculation had been undertaken nor give any justification for the numbers of participants needed to detect an effect of differences in fruit and vegetable intake and the incidence of type 2 diabetes. All papers

\section{Table 1 |Characteristics of included studies on fruit and vegetable intake and risk of type 2 diabetes}

\begin{tabular}{|c|c|c|c|c|c|c|c|c|c|}
\hline & No & $\begin{array}{l}\text { No } \\
\text { of cases/ } \\
\text { non-cases }\end{array}$ & Age (years) & Measure of intake & $\begin{array}{l}\text { Confounders } \\
\text { measured }\end{array}$ & $\begin{array}{l}\text { Follow-up } \\
\text { (years) }\end{array}$ & $\begin{array}{l}\text { Assessment of } \\
\text { type } 2 \text { diabetes }\end{array}$ & $\begin{array}{c}\text { Quantity (highest } v \\
\text { lowest intakes as } \\
\text { servings/day) }\end{array}$ & $\begin{array}{l}\text { Quality } \\
\text { score }\end{array}$ \\
\hline $\begin{array}{l}\text { Villegas et al } 2008,^{36} \\
\text { Shanghai Women's } \\
\text { Health Study, China }\end{array}$ & $\begin{array}{l}64191 \\
\text { women }\end{array}$ & $896 / 63295$ & $40-70$ & $\begin{array}{l}\text { Personal interview FFQ, } \\
\text { calculated g/day for fruit and } \\
\text { vegetables separately. Defined } \\
\text { green leafy vegetables as } \\
\text { greens/Chinese greens/ } \\
\text { spinach. Data divided into fifths. } \\
\text { Calculated hazard ratio }\end{array}$ & $\begin{array}{l}\text { BMI, WHR, age, level of } \\
\text { education, smoking } \\
\text { status, alcohol use, } \\
\text { hypertension, disease } \\
\text { history, hormone use, } \\
\text { occupational history, } \\
\text { physical activity }\end{array}$ & 4.6 & $\begin{array}{l}\text { Confirmed by ADA } \\
\text { criteria }\end{array}$ & $\begin{array}{l}\text { Fruit: } 4.56 v 0.82 . \\
\text { Vegetables: } 4.04 v \\
1.15 . \text { Green leafy } \\
\text { vegetables: } 1.28 v \\
0.26\end{array}$ & 4 \\
\hline $\begin{array}{l}\text { Bazzano et al } 2008,^{37} \\
\text { Nurses Health Study } \\
\text { USA (1984 onwards) }\end{array}$ & $\begin{array}{l}71346 \\
\text { women }\end{array}$ & $\begin{array}{c}4529 / 66 \\
817\end{array}$ & $30-55$ & $\begin{array}{l}\text { Self completed FFQ. Calculated } \\
\text { servings/day of fruit, vegetables } \\
\text { and combined. Defined green } \\
\text { leafy vegetables as spinach/ } \\
\text { kale/lettuce. Data divided into } \\
\text { fifths. Calculated hazard ratio }\end{array}$ & $\begin{array}{l}\text { BMI, physical activity, } \\
\text { smoking status, } \\
\text { alcohol use, hormone } \\
\text { therapy, family history, } \\
\text { hypertension, } \\
\text { cholesterol }\end{array}$ & 18 & $\begin{array}{l}\text { Confirmed if met } \\
\text { WHO criteria } \\
\text { (before 1997) or } \\
\text { ADA criteria (after } \\
\text { 1998) }\end{array}$ & $\begin{array}{l}\text { Fruit: } 2.5 v 0.5 . \\
\text { Vegetables: } 5.2 \mathrm{v} \\
\text { 1.5. Fruit and } \\
\text { vegetables: } 7.5 \mathrm{v} \\
\text { 2.1. Green leafy } \\
\text { vegetable: data not } \\
\text { given }\end{array}$ & 4 \\
\hline $\begin{array}{l}\text { Montonen et al } \\
2005,^{38} \text { Finnish } \\
\text { Mobile Clinic Health } \\
\text { Examination Survey }\end{array}$ & $\begin{array}{c}4304 \\
\text { men and } \\
\text { women }\end{array}$ & $383 / 3921$ & $40-69$ & $\begin{array}{l}\text { Dietary history interview. } \\
\text { Calculated g/day for fruit and } \\
\text { vegetables separately. Gave no } \\
\text { definition for green leafy } \\
\text { vegetables. Data divided into } \\
\text { quarters. Calculated relative } \\
\text { risks }\end{array}$ & $\begin{array}{l}\text { Occupation, illness, } \\
\text { medication, health } \\
\text { status, smoking } \\
\text { status, blood pressure }\end{array}$ & 23 & $\begin{array}{l}\text { Confirmed via } \\
\text { social insurance } \\
\text { institutions } \\
\text { register }\end{array}$ & $\begin{array}{l}\text { Fruit: }>1.47 v<0.31 \\
\text { Vegetables: }>1.23 v \\
<0.4 . \text { Green leafy } \\
\text { vegetables: }>0.4 v \\
<0.1\end{array}$ & 3 \\
\hline $\begin{array}{l}\text { Liu et al } 2004,^{39} \\
\text { Women's Health } \\
\text { Study, USA }\end{array}$ & $\begin{array}{l}38018 \\
\text { women }\end{array}$ & $\begin{array}{c}1614 / 36 \\
404\end{array}$ & $\geq 45$ & $\begin{array}{l}\text { Self completed FFQ. Calculated } \\
\text { servings/day for fruit, } \\
\text { vegetables and combined. } \\
\text { Defined green leafy vegetables } \\
\text { as spinach/kale/lettuce. Data } \\
\text { divided into fifths. Calculated } \\
\text { relative risks }\end{array}$ & $\begin{array}{l}\text { BMI, smoking status, } \\
\text { alcohol use, exercise, } \\
\text { family history, } \\
\text { menopausal state, } \\
\text { vitamin use, blood } \\
\text { pressure, cholesterol }\end{array}$ & 8.8 & $\begin{array}{l}\text { Based on self } \\
\text { reported }\end{array}$ & $\begin{array}{l}\text { Fruit: } 3.91 v 0.62 . \\
\text { Vegetables: } 6.84 v \\
1.47 . \text { Fruit and } \\
\text { vegetables: } 10.16 v \\
2.54 . \text { Green leafy } \\
\text { vegetables: } 1.42 v \\
0.14\end{array}$ & 3 \\
\hline $\begin{array}{l}\text { Ford et al } 2001,{ }^{40} \\
\text { NHANES, USA }\end{array}$ & $\begin{array}{l}9665 \\
\text { men and } \\
\text { women }\end{array}$ & $1018 / 8647$ & $25-74$ & $\begin{array}{l}\text { Single } 24 \text { hour recall. Calculated } \\
\text { servings/week for fruit and } \\
\text { vegetables combined. Data } \\
\text { divided into thirds. Calculated } \\
\text { hazard ratios }\end{array}$ & $\begin{array}{l}\text { BMI, age, ethnicity } \\
\text { smoking, blood } \\
\text { pressure, } \\
\text { hypertension } \\
\text { medication, } \\
\text { cholesterol, exercise, } \\
\text { alcohol, education }\end{array}$ & 20 & $\begin{array}{l}\text { Confirmed either } \\
\text { by self report or } \\
\text { hospital records }\end{array}$ & $\begin{array}{l}\text { Fruit and vegetables: } \\
>5 \vee 0\end{array}$ & 1 \\
\hline $\begin{array}{l}\text { Meyer et al } 2000,^{41} \\
\text { lowa Women's Health } \\
\text { Study, USA }\end{array}$ & $\begin{array}{l}35988 \\
\text { women }\end{array}$ & $\begin{array}{c}1141 / 34 \\
847\end{array}$ & $55-69$ & $\begin{array}{l}\text { Self completed FFQ. Calculated } \\
\text { servings/day for fruit, } \\
\text { vegetables, and combined. Data } \\
\text { divided into fifths. Calculated } \\
\text { hazard ratios }\end{array}$ & $\begin{array}{l}\text { BMI, WHR, age, level of } \\
\text { education, physical } \\
\text { activity, smoking } \\
\text { habits, alcohol intake, } \\
\text { medication use, }\end{array}$ & 6 & $\begin{array}{l}\text { Based on self } \\
\text { reported }\end{array}$ & $\begin{array}{l}\text { Fruit: } 3.36 v 0.57 . \\
\text { Vegetables: } 5.93 \mathrm{v} \\
1.57 . \text { Fruit and } \\
\text { vegetables: } 8.86 \mathrm{v} \\
2.57\end{array}$ & 2 \\
\hline
\end{tabular}

$\mathrm{FFQ}=$ food frequency questionnaire, $\mathrm{BMI}=$ body mass index, WHR=weight:height ratio, ADA=American Diabetes Association. 
Table 2 | Meta-analysis of highest versus lowest intake of fruit and vegetables and risk of type 2 diabetes

\begin{tabular}{|c|c|c|c|c|}
\hline Comparison & No of studies & Cases/non-cases & $\begin{array}{c}\text { Pooled HR }(95 \% \mathrm{Cl}), \\
\text { P value }\end{array}$ & $\begin{array}{c}\text { Heterogeneity }(\mathrm{I} 2), \\
\text { P value }\end{array}$ \\
\hline Vegetables only & $5^{36-3941}$ & $8563 / 204654$ & 0.91 (0.76 to 1.09$), 0.32$ & $78.1,0.001$ \\
\hline Fruit only & $5^{36-3941}$ & $8563 / 204654$ & 0.93 (0.83 to 1.01 ), 0.27 & $52.6,0.07$ \\
\hline Fruit and vegetables & $4^{3739-41}$ & $8302 / 146715$ & 1.00 (0.92 to 1.09 ), 0.97 & $0,0.40$ \\
\hline Green leafy vegetables & $4^{36-39}$ & $7422 / 169807$ & 0.86 (0.77 to 0.97$), 0.01$ & $39.6,0.18$ \\
\hline
\end{tabular}

made some adjustments for potential confounding factors; only three, however, adjusted for age, BMI, and family history of type 2 diabetes. ${ }^{37-39}$ Only two papers used appropriate inclusion and exclusion criteria $^{3637}$ (we assumed that authors should have excluded patients with a history of type 2 diabetes, cancer, or cardiovascular disease and those with implausibly high or low dietary intake). Two papers ${ }^{3840}$ did not use what we considered to be a validated tool to assess fruit and vegetable intake. ${ }^{25}$

Publication bias was assessed by visually examining a funnel plot of precision against hazard ratio (not shown), with asymmetry being formally assessed with the Egger test; no significant bias was shown $(\mathrm{P}=0.27)$.

\section{Analysis of summary estimates}

The summary estimates of hazard ratios or relative risks from each publication were pooled to give a total estimate of risk (table 2). We specifically looked at lowest intake values versus highest intake values. The meta-analysis did not show any significant reductions in risk of type 2 diabetes incidence for consumption of fruit, vegetables, or vegetables and fruit combined (figs 2, 3, and 4), though the data do suggest a trend towards a benefit of consuming greater quantities (table 2). All studies that examined intake of green leafy vegetables showed a benefit of consuming greater quantities (fig 5). Summary estimates showed that consuming 1.35 servings a day of green leafy vegetables (highest intake) compared with 0.2 servings (lowest intake) resulted in a $14 \%$ reduction in risk $(\mathrm{P}=0.01)$ of type 2 diabetes (hazard ratio $0.86,95 \%$ confidence interval 0.77 to 0.96 )

Because of the significant heterogeneity observed between studies we carried out a sensitivity analysis (table 3). We separately analysed quality of articles, sex, length of follow-up, and location as these were assumed to be potential sources of bias. We also investigated whether the different ways in which authors had grouped intake (thirds, quarters, or fifths) affected the results. There were no significant interactions between any of these variables that would explain the heterogeneity seen. In addition we re-ran the metaanalysis to include the EPIC study, ${ }^{35}$ which presented data as odds ratios. Inclusion of this study did not alter the associations previously observed.

\section{DISCUSSION}

\section{Principal finding}

Increasing the amount of green leafy vegetables in an individual's diet could help to reduce the risk of type 2 diabetes. An increase of 1.15 servings a day was associated with a $14 \%$ decrease in incidence. The data did not show any significant relations between the consumption of fruits, vegetables, or fruit and vegetables combined on the incidence of diabetes. As there was significant heterogeneity between studies, however, we carried out a sensitivity analysis. This showed no significant interactions between the outcomes of variables examined, and thus could not identify differences that occurred between the studies.

\section{Exploration of heterogeneity}

Within the sensitivity analysis we examined location as a possible source of heterogeneity. As traditional Chinese diets are high in fruit and vegetables, ${ }^{42}$ we would expect that intake would be greater in China than the US or Europe. Intake, however, was quite similar. This might reflect a change from traditional foods of China to a more westernised diet.

We also examined sex as a possible source of heterogeneity; again this did not show any significant interaction between variables. Only two of the studies included men, both of which showed significant benefits of increasing intake of fruit and vegetables. Our results might have been different if the studies in our meta-analysis had included more men. Further studies in men are required before firm conclusions can be made.

Although the sensitivity analysis could not explain the level of heterogeneity, it could be because of several differences between the studies. Estimations of daily consumption differed between the studies. Ford and Mokdad estimated servings per week, ${ }^{40}$ intake from three studies was calculated as servings per day, ${ }^{373941}$ and the two remaining studies ${ }^{353638}$ calculated grams per day. To carry out the meta-analysis we had to standardise all data into servings per day, therefore conclusions should be drawn with caution.

We standardised all data using a standard portion size of $106 \mathrm{~g}$, in agreement with other meta-analysis studies that have analysed fruit and vegetable intake and risk of chronic disease. ${ }^{2029}$ The current UK recommendation to consume five portions of fruit and vegetables a day, however, is based on $80 \mathrm{~g}$ as a serving size. Therefore from our analysis we can calculate that increasing consumption of green leafy vegetables by one and a half UK portions a day $(121.9 \mathrm{~g})$ could result in $14 \%$ reduction in the incidence of type 2 diabetes.

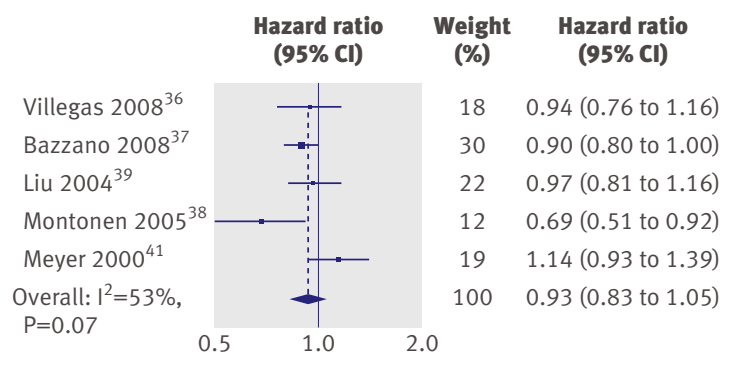

Fig 3 | Hazard ratios for incidence in diabetes type 2 for highest versus lowest intake of fruit. Weights are from random effects analysis 


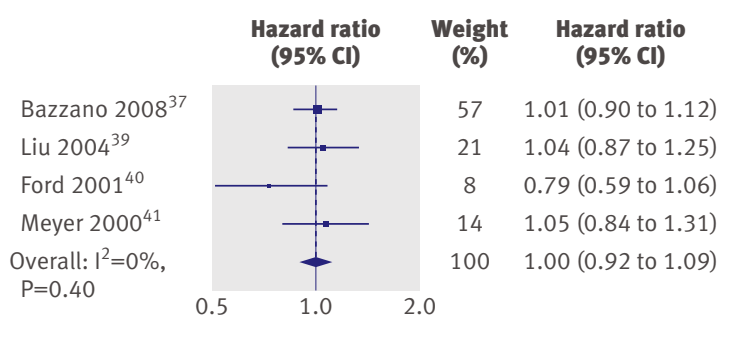

Fig 4 | Hazard ratios for incidence in diabetes type 2 for highest versus lowest intake of fruit and vegetables combined. Weights are from random effects analysis

In addition to calculating intake in different formats the studies also grouped foods differently. Three studies examined intake of fruit and vegetables separately and combined,,$^{373941}$ one study examined combined consumption, ${ }^{40}$ and two examined intake separately. ${ }^{3638}$ These two papers both showed significant benefits of greater consumption of fruit, vegetables, and green leafy vegetables. They did not, however, explain why they did not report combined data, and this could reflect a bias in the reporting of positive results.

The different studies also split dietary intake into different fractions, either thirds, ${ }^{39}$ quarters, ${ }^{37}$ or fifths. ${ }^{35363840}$ Sensitivity analysis showed that this made no significant difference to the results.
Heterogeneity could also be caused by differences in classification of food groups. The studies that investigated green leafy vegetables did not all use the same criteria; two papers included spinach, kale, and lettuce, ${ }^{3739}$ another included Chinese greens, greens, and spinach, ${ }^{36}$ and the other paper did not provide a definition. ${ }^{38}$ This shows a need for one uniform definition of different fruit and vegetable groups. Green leafy vegetables actually include brassicas, such as cabbage, brussel sprouts, and cauliflower; Compositae, such as lettuce; and umbelliferous vegetables, which are plants grown for their leaves and stems and are often consumed as herbs, such as parsley, dill, and fennel. Other leafy vegetables such as spinach are also included. ${ }^{43}$ The investigators did not include all of these foods in their categories of green leafy vegetable; if they were included the observed results might differ.

Another possible explanation for the differences between the studies might be the method of dietary assessment. Ford and Mokdad collected data via a single 24 hour recall, ${ }^{40}$ two studies used dietary assessment interviews, ${ }^{3638}$ and the remaining studies used self completed food frequency questionnaires. Assessment of true dietary intake is inherently difficult, and the use of food frequency questionnaires has been criticised. ${ }^{445}$ They are subject to a combination of random and systematic errors. ${ }^{46}$ These errors in

Table 3 | Sensitivity analysis to investigate differences between studies included in meta-analysis

\begin{tabular}{|c|c|c|c|c|c|c|c|c|c|c|c|c|}
\hline & \multicolumn{3}{|c|}{ Vegetables only } & \multicolumn{3}{|c|}{ Fruit only } & \multicolumn{3}{|c|}{ Fruit and vegetables } & \multicolumn{3}{|c|}{ Leafy green vegetables } \\
\hline & No & $\begin{array}{c}\text { Pooled HR } \\
(95 \% \mathrm{Cl})\end{array}$ & $\begin{array}{c}P \\
\text { value }\end{array}$ & No & $\begin{array}{c}\text { Pooled HR } \\
(95 \% \mathrm{Cl})\end{array}$ & $P$ value & No & $\begin{array}{c}\text { Pooled HR } \\
(95 \% \mathrm{Cl})\end{array}$ & $P$ value & No & $\begin{array}{c}\text { Pooled HR } \\
(95 \% \mathrm{Cl})\end{array}$ & $P$ value \\
\hline \multicolumn{13}{|l|}{ Quality: } \\
\hline High (4/5) & 2 & $\begin{array}{c}0.84 \\
(0.52 \text { to } 1.34)\end{array}$ & \multirow{2}{*}{0.61} & 2 & $\begin{array}{c}0.91 \\
(0.82 \text { to } 1.00)\end{array}$ & \multirow{2}{*}{0.87} & 1 & $\begin{array}{c}1.01 \\
(0.91 \text { to } 1.13)\end{array}$ & \multirow{2}{*}{0.87} & 2 & $\begin{array}{c}0.86 \\
(0.76 \text { to } 0.98)\end{array}$ & \multirow{2}{*}{0.94} \\
\hline Low («4) & 3 & $\begin{array}{c}0.98 \\
(0.82 \text { to } 1.16)\end{array}$ & & 3 & $\begin{array}{c}0.94 \\
(0.73 \text { to } 1.19)\end{array}$ & & 3 & $\begin{array}{c}0.98 \\
(0.84 \text { to } 1.15)\end{array}$ & & 2 & $\begin{array}{c}0.84 \\
(0.61 \text { to } 1.15)\end{array}$ & \\
\hline \multicolumn{13}{|l|}{ Sex: } \\
\hline Men and women & 1 & $\begin{array}{c}0.77 \\
(0.57 \text { to } 1.04)\end{array}$ & \multirow{2}{*}{0.54} & 1 & $\begin{array}{c}0.69 \\
(0.51 \text { to } 0.93)\end{array}$ & \multirow{2}{*}{0.14} & 1 & $\begin{array}{c}0.79 \\
(0.59 \text { to } 1.06)\end{array}$ & \multirow{2}{*}{0.23} & 1 & $\begin{array}{c}0.69 \\
(0.51 \text { to } 0.94)\end{array}$ & \multirow{2}{*}{0.31} \\
\hline Women only & 4 & $\begin{array}{c}0.94 \\
(0.77 \text { to } 1.15)\end{array}$ & & 4 & $\begin{array}{c}0.96 \\
(0.86 \text { to } 1.06)\end{array}$ & & 3 & $\begin{array}{c}1.02 \\
(0.94 \text { to } 1.12)\end{array}$ & & 3 & $\begin{array}{c}0.89 \\
(0.81 \text { to } 0.98)\end{array}$ & \\
\hline \multicolumn{13}{|c|}{ Length of follow-up (years): } \\
\hline$<10$ & 3 & $\begin{array}{c}0.90 \\
(0.67 \text { to } 1.21)\end{array}$ & \multirow{2}{*}{0.92} & 3 & $\begin{array}{c}1.01 \\
(0.90 \text { to } 1.13)\end{array}$ & \multirow{2}{*}{0.19} & 2 & $\begin{array}{c}1.04 \\
(0.91 \text { to } 1.20)\end{array}$ & \multirow{2}{*}{0.54} & 2 & $\begin{array}{c}0.87 \\
(0.71 \text { to } 1.07)\end{array}$ & \multirow{2}{*}{0.77} \\
\hline$\geq 10$ & 2 & $\begin{array}{c}0.93 \\
\text { (0.69 to } 1.25)\end{array}$ & & 2 & $\begin{array}{c}0.82 \\
(0.64 \text { to } 1.05)\end{array}$ & & 2 & $\begin{array}{c}0.93 \\
(0.74 \text { to } 1.17)\end{array}$ & & 2 & $\begin{array}{c}0.82 \\
(0.64 \text { to } 1.05)\end{array}$ & \\
\hline \multicolumn{13}{|l|}{ Location: } \\
\hline US and Europe & 4 & $\begin{array}{c}1.02 \\
(0.92 \text { to } 1.12)\end{array}$ & \multirow{2}{*}{0.23} & 4 & $\begin{array}{c}0.93 \\
(0.80 \text { to } 1.08)\end{array}$ & \multirow{2}{*}{0.97} & 4 & $\begin{array}{c}1.00 \\
(0.92 \text { to } 1.09)\end{array}$ & \multirow{2}{*}{-} & 3 & $\begin{array}{c}0.89 \\
(0.78 \text { to } 1.01)\end{array}$ & \multirow{2}{*}{0.73} \\
\hline China & 1 & $\begin{array}{c}0.65 \\
(0.52 \text { to } 0.81)\end{array}$ & & 1 & $\begin{array}{c}0.94 \\
(0.76 \text { to } 1.16)\end{array}$ & & 0 & - & & 1 & $\begin{array}{c}0.78 \\
(0.64 \text { to } 0.96)\end{array}$ & \\
\hline \multicolumn{13}{|c|}{ Fractions of distribution: } \\
\hline Thirds & 0 & - & \multirow{3}{*}{0.54} & 0 & - & \multirow{3}{*}{0.14} & 1 & $\begin{array}{c}0.79 \\
(0.59 \text { to } 1.06)\end{array}$ & \multirow{3}{*}{0.23} & 0 & - & \multirow{3}{*}{0.31} \\
\hline Quarters & 1 & $\begin{array}{c}0.77 \\
(0.57 \text { to } 1.04)\end{array}$ & & 1 & $\begin{array}{c}0.69 \\
(0.51 \text { to } 0.93)\end{array}$ & & 0 & - & & 1 & $\begin{array}{c}0.69 \\
(0.51 \text { to } 0.94)\end{array}$ & \\
\hline Fifths & 4 & $\begin{array}{c}0.94 \\
(0.77 \text { to } 1.15)\end{array}$ & & 4 & $\begin{array}{c}0.96 \\
(0.88 \text { to } 1.06)\end{array}$ & & 3 & $\begin{array}{c}1.02 \\
(0.94 \text { to } 1.12)\end{array}$ & & 3 & $\begin{array}{c}0.89 \\
(0.81 \text { to } 0.98)\end{array}$ & \\
\hline With EPIC study ${ }^{32}$ & 6 & $\begin{array}{c}0.90 \\
(0.76 \text { to } 1.05)\end{array}$ & - & 6 & $\begin{array}{c}0.90 \\
(0.79 \text { to } 1.02)\end{array}$ & - & 5 & $\begin{array}{c}0.96 \\
(0.86 \text { to } 1.07)\end{array}$ & - & 5 & $\begin{array}{c}0.86 \\
(0.78 \text { to } 0.94)\end{array}$ & - \\
\hline
\end{tabular}

$\mathrm{HR}=$ hazard ratio. 
measurement can underestimate true interactions between diet and disease. ${ }^{478}$ Such attenuation could have masked an association in our meta-analysis. Indeed studies have previously shown that interactions between diet and disease have been masked by the use of food frequency questionnaires but identified by food diaries and nutritional biomarkers. ${ }^{49-51}$ The use of biomarkers avoids problems associated with self report, and they can be collected for large numbers of participants. Thus there is a need to incorporate more biological markers of fruit and vegetable intake, such as plasma vitamin $\mathrm{C}$ concentration, into prospective nutritional assessment studies.

In our meta-analysis we included the most fully adjusted hazard ratio presented in the articles. Not all authors of the primary articles made the same adjustments, and this might have had an impact on our overall dataset. Indeed, only three of the six ${ }^{37-39}$ adjusted for what we considered in our quality assessment tool as essential confounders, (age, BMI, and family history of type 2 diabetes).

\section{Potential benefits of green leafy vegetables}

Although our results for fruit and vegetable consumption were not significant, the data do suggest a trend towards a benefit of consuming greater quantities; this supports evidence previously reported in cross sectional studies. ${ }^{3452}$ In addition several studies examining dietary patterns and incidence of type 2 diabetes have consistently shown that fruit and vegetables are important components of the dietary patterns associated with a decreased risk of type 2 diabetes. ${ }^{53-55}$

A possible benefit of fruit and vegetables in the prevention of chronic diseases is from their antioxidant content and thus a contribution to reduction of systemic oxidative stress. Our results support this as green leafy vegetables, such as spinach, have been shown to contain high concentrations of $\beta$ carotene and vitamin $\mathrm{C},{ }^{56}$ both of which confer antioxidant properties. Green leafy vegetables also contain poly phenols,${ }^{57}$ which are known for their antioxidant properties. Green leafy vegetables might reduce the risk of type 2 diabetes because of their magnesium content. A recent meta-analysis found magnesium intake to be inversely associated with incidence of type 2 diabetes. ${ }^{58}$ Green leafy vegetables are also good sources of $\alpha$ linolenic acid, ${ }^{59}$ which is an omega 3 polyunsaturated fatty acid. The fatty acid profile of the diet is thought to be important in determining the fatty acid composition of the phospholipid bilayer. The composition of this bilayer is related to insulin sensitivity within skeletal muscle. ${ }^{60}$ Thus there are several possible mechanisms that could explain the benefit of consuming green leafy vegetables in the diet. Our results support the evidence that "foods" rather than isolated components such as antioxidants are beneficial for health. Results from several supplement trials have produced disappointing results for prevention of disease, in contrast with epidemiological evidence. ${ }^{6162}$ Further investigation is warranted to understand the mechanisms involved in the proposed relation

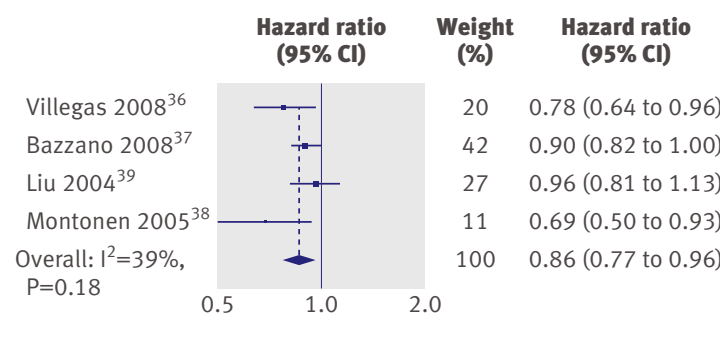

Fig 5 | Hazard ratios for incidence in diabetes type 2 for highest versus lowest intake of green leafy vegetables. Weights are from random effects analysis

between green leafy vegetables and risk of type 2 diabetes.

\section{Strengths and limitations}

We carried out a broad search of both medical subject headings and keywords that covered diabetes and fruit and vegetable consumption. The search was conducted on multiple databases and was carried out by two independent authors. In addition we contacted all authors of included articles to request any further information.

As with all meta-analysis, several limitations must be considered. Publication bias is a potential concern in analyses of published studies. The statistical tests we carried out, however, suggest that bias was not present. The statistical power of the study might be limited as we included only six studies and only four studies for the examination of green leafy vegetables. In addition the meta-analysis includes only one study from Europe, highlighting a lack of potentially important information.

There was significant heterogeneity between the included studies so overall conclusions must be regarded with caution. We did, however, carry out a thorough sensitivity analysis to investigate possible sources of heterogeneity.

To further examine the association between intake and risk of type 2 diabetes we investigated the possibility of carrying out a dose-response analysis. Only one paper, however, provided the information required. ${ }^{36}$ In addition, four out of the six studies included were given quality assessment scores of less than $4 .^{38-41}$ When these studies were removed from the analysis the results did not significantly alter, so conclusions must be drawn with caution. Previous studies have also shown that greater intake of fruit and vegetables is linked to other lifestyle factors such as physical activity. ${ }^{52}$ We cannot rule out the possibility that other variables, which were not adequately controlled for, might have influenced the data from these studies. The results highlight a call for standardisation of nutritional epidemiology, with emphasis on the additional use of biological markers and uniformity of food groups.

\section{Conclusions and implications}

Results from our meta-analysis support recommendations to promote the consumption of green leafy 


\section{WHAT IS ALREADY KNOWN ON THIS TOPIC}

\section{Prevalence of type 2 diabetes is increasing worldwide}

Consumption of fruits and vegetables is beneficial in the prevention of cardiovascular disease and cancer, yet consumption remains low throughout the world, including the UK

\section{WHAT THIS STUDY ADDS}

Increasing intake of green leafy vegetables is significantly associated with a reduced incidence of type 2 diabetes

Significant heterogeneity observed between studies suggests a need for increased inclusion of nutritional biomarkers and less reliance on food frequency questionnaires within nutritional observational studies changes in lifestyle among subjects with impaired glucose tolerance. N Engl J Med 2001;344:1343-50.

8 Knowler WC, Barrett-Connor E, Fowler SE, Hamman RF, Lachin JM, Walker EA, et al. Reduction in the incidence of type 2 diabetes with lifestyle intervention or metformin. N Engl J Med 2002;346:393-403.

9 Hall JN, Moore S, Harper SB, Lynch JW. Global variability in fruit and vegetable consumption. Am J Prev Med 2009;36:402-9.

10 Henderson L, Gregory J, Swan G. National diet and nutrition survey: adults aged 19 to 64 years. Types and quantities of foods consumed. Stationery Office, 2002.

11 Lock K, Pomerleau J, Causer L, Altman DR, McKee M. The global burden of disease attributable to low consumption of fruit and vegetables: implications for the global strategy on diet. Bull World Health Organ 2005;83:100-8.

12 Van't Veer P, Jansen MC, Klerk M, Kok FJ. Fruits and vegetables in the prevention of cancer and cardiovascular disease. Public Health Nutr 2000;3:103-7.

13 Pomerleau J, Lock K, McKee M. The burden of cardiovascular disease and cancer attributable to low fruit and vegetable intake in the European Union: differences between old and new member states. Public Health Nutr 2006;9:575-83.

vegetables in the diet for reducing the risk of type 2 diabetes. The results support the growing body of evidence that lifestyle modification is an important factor in the prevention of type 2 diabetes. ${ }^{6-8}$ The potential for tailored advice on increasing intake of green leafy vegetables to reduce the risk of type 2 diabetes should be investigated further.

We thank Nita Forouhi from the Medical Research Council Epidemiology Unit, Institute of Metabolic Science, Cambridge, for her detailed contribution and advice. We also thank Sarah Sutton, clinical librarian, and Janette Camosso-Stefinovic, information librarian, for their input to the search strategy.

Contributors: PC, KK, and MJD had the original idea for the review. KK and MJD developed the search protocol for the review with PC. PC performed the literature review, extracted and analysed data, and wrote the first draft of the article. JT also reviewed, extracted, and analysed data. LJG performed the statistical analysis. All authors contributed to the writing of the paper and gave input at all stages of the study. PC is guarantor. Funding and study sponsor: The research was funded by the Cardiovascular Research Department, University of Leicester. PC is being funded for a PhD in the department. All members of the research team are either employees of the University of Leicester or the University Hospitals of Leicester NHS Trust. We acknowledge ongoing support from NIHRCLAHRC.

Competing interests: All authors have completed the Unified Competing Interest form at www.icmje.org/coi_disclosure.pdf (available on request from the corresponding author) and declare that (1) no financial support for the submitted work from anyone other than their employer; (2) no financial relationships with commercial entities that might have an interest in the submitted work in the previous 3 years; (3) no spouses, partners, or children with relationships with commercial entities that may be relevant to the submitted work; and (4) KK and MJD have received grants from the National Institute of Health Research (NIHR) for studies on the prevention of type 2 diabetes.

Ethical approval: Not required.

Data sharing: Dataset available from the corresponding author.

1 Shaw JE, Sicree RA, Zimmet PZ. Global estimates of the prevalence of diabetes for 2010 and 2030. Diabetes Res Clin Pract 2010;87:4-14.

2 Schulze MB, Hu FB. Primary prevention of diabetes: what can be done and how much can be prevented? Annu Rev Public Health 2005;26:445-67.

3 Steyn NP, Mann J, Bennett PH, Temple N, Zimmet P, Tuomilehto J, et al. Diet, nutrition and the prevention of type 2 diabetes. Public Health Nutr 2004;7:147-65.

4 Gillies CL, Abrams KR, Lambert PC, Cooper NJ, Sutton AJ, Hsu RT, et al. Pharmacological and lifestyle interventions to prevent or delay type 2 diabetes in people with impaired glucose tolerance: systematic review and meta-analysis. BMJ 2007;344:299.

5 Eriksson KF, Lindgarde F. Prevention of type 2 (non-insulindependent) diabetes mellitus by diet and physical exercise. The 6year Malmo feasibility study. Diabetologia 1991;34:891-8.

6 Pan X, Li G, Hu Y, Wang J, Yang W, An Z, et al. Effects of diet and exercise in preventing NIDDM in people with impaired glucose tolerance. Diabetes Care 1997;20:537-44.

7 Tuomilehto J, Lindstrom J, Eriksson JG, Valle TT, Hamalainen $\mathrm{H}$, llanne-Parikka P, et al. Prevention of type 2 diabetes mellitus by
14 Gerstein HC, Pogue J, Mann JFE, Lonn E, Dagenai GR, McQueen M, Yusuf S. The relationship between dysglycaemia and cardiovascular and renal risk in diabetic and non-diabetic participants in the HOPE study: a prospective epidemiological analysis. Diabetologia 2005;2009:1749-55.

15 Liu S, Manson JE, Lee IM, Cole SR, Hennekens CH, Willett WC, et al. Fruit and vegetable intake and risk of cardiovascular disease: the Women's Health Study. Am J Clin Nutr 2000;72:922-8.

16 Miller HE, Rigelhof F, Marquart L, Prakash A, Kanter M. Antioxidant content of whole grain breakfast cereals, fruit and vegetables. J Am Coll Nutr 2000;19:312-9S.

17 Broekmans WMR, Klopping-Ketelaars IAA, Schuurman CRWC Verhagen $\mathrm{H}$, van den Berg $\mathrm{H}$, Kok FJ, et al. Fruits and vegetables increase plasma carotenoids and vitamins and decrease homocysteine in humans. J Nutr 2000;130:1578-83.

18 Zino S, Skeaff M, Williams S, Mann J. Randomised controlled trial of effect of fruit and vegetable consumption on plasma concentrations of lipids and antioxidants. BMJ 1997;314:1787-91.

19 Asgard R, Rytter E, Basu S, Abramsson-Zetterberg L, Moller L, Vessby $B$. High intake of fruit and vegetables is related to low diabetes. Scand / Food Nutr 2007;51:149-58.

20 Hamer M, Chida Y. Intake of fruit, vegetables, and antioxidants and risk of type 2 diabetes: systematic review and meta-analysis. J Hypertens 2007;25:2361-9.

21 Cochrane Collaboration. Cochrane handbook for systematic reviews of interventions. 2009. www.cochrane-handbook.org.

22 Centre for Reviews and Dissemination. Systematic reviews: CRD's guidance for undertaking reviews in health care. University of York, 2009.

23 ADA. Report of the expert committee on the diagnosis and classification of diabetes mellitus. Diabetes Care 1997;20:1183-97.

24 World Health Organization. Definition and diagnosis of diabetes mellitus and intermediate hyperglycaemia. WHO, 2009. www.idf. org/webdata/docs/WHO_IDF_definition_diagnosis_of_diabetes. pdf.

25 Block G. A review of validations of dietary assessment methods. Am J Epidemiol 1982;115:492-505.

26 Stroup DF, Berlin JA, Morton SC, Olkin I, Williamson GD, Rennie D, et al. Meta-analysis of observational studies in epidemiology. A proposal for reporting. JAMA 2000;283:2008-12.

27 Wong WCW, Cheung CSK, Hart GJ. Development of a quality assessment tool for systematic reviews of observational studies (QATSO) of HIV prevalence in men having sex with men and associated risk behaviours. Emerg Themes Epidemiol 2008;5:23.

28 Von Elm E, Altman DG, Egger M, Pocock SJ, Gotzsch PC, studies in epidemiology (STROBE) statement: guidelines for reporting observational studies. / Clin Epidemiol 2008;61:344-9.

29 Dauchet L, Amouyel P, Hercberg S, Dallongeville J. Fruit and vegetable consumption and risk of coronary heart disease: a metaanalysis of cohort studies. J Nutr 2006;136:2588-93.

30 Altman DG, Bland JM. Interaction revisited: the difference between two estimates. BMJ 2003;326:219.

31 DerSimonian R, Laird N. Meta-analysis in clinical trials. Control Clin Trials 1986;7:177-88.

32 Colditz GA, Manson JE, Stampfer MJ, Rosner B, Willett WC, Speizer FE. Diet and risk of clinical diabetes in women. Am J Clin Nutr 1992;55:1018-23.

33 Sargeant LA, Khaw KT, Bingham S, Day NE, Luben RN, Oakes S, et al. Fruit and vegetable intake and population glycosylated haemoglobin levels: the EPIC-Norfolk study. Eur / Clin Nutr 2001;55:342-8.

34 Feskens EJ, Virtanen SM, Rasanen L, Tuomilehto J, Stengard J, oxidative stress and inflammation in a group of patients with type 2 Vandenbroucke JP. The strengthening the reporting of observational Pekkanen J, et al. Dietary factors determining diabetes and impaired 
glucose tolerance. A 20-year follow-up of the Finnish and Dutch cohorts of the Seven Countries Study. Diabetes Care 1995;18:1104-12.

35 Harding AH, Wareham NJ, Bingham SA, Khaw K, Luben R, Welch A, et al. Plasma vitamin $\mathrm{C}$ level, fruit and vegetable consumption, and the risk of new-onset type 2 diabetes mellitus: the European prospective investigation of cancer-Norfolk prospective study. Arch Intern Med 2008;168:1493-9.

36 Villegas R, Shu XO, Gao YT, Yang G, Elasy T, Li H, et al. Vegetable but not fruit consumption reduces the risk of type 2 diabetes in Chinese women. J Nutr 2008;138:574-80.

37 Bazzano LA, Li TY, Joshipura KJ, Hu FB. Intake of fruit, vegetables, and fruit juices and risk of diabetes in women. Diabetes Care 2008;31:1311-7.

38 Montonen J, Jarvinen R, Heliovaara M, Reunanen A, Aromaa A, Knekt $P$. Food consumption and the incidence of type II diabetes mellitus. Eur J Clin Nutr 2005;59:441-8.

39 Liu S, Serdula M, Janket SJ, Cook NR, Sesso HD, Willett WC, et al. A prospective study of fruit and vegetable intake and the risk of type 2 diabetes in women. Diabetes Care 2004;27:2993-6.

40 Ford ES, Mokdad AH. Fruit and vegetable consumption and diabetes mellitus incidence among US adults. Prev Med 2001;32:33-9.

41 Meyer KA, Kushi LH, Jacobs DR Jr, Slavin J, Sellers TA, Folsom AR. Carbohydrates, dietary fiber, and incident type 2 diabetes in older women. Am J Clin Nutr 2000;71:921-30.

42 Woo J, Woo KS, Leung SSF, Chook P, Liu B, Ip B, et al. The Mediterranean score of dietary habits in Chinese populations in four different geographical areas. Eur J Clin Nutr 2001;55:215-20.

43 Southgate DAA. Vegetables, fruits, fungi and their products. In: Garrow JS, James WPT, Ralph A, eds. Human nutrition and dietetics. 10th ed. Churchill Livingstone, 2000:349-62.

44 Schatzkin A, Kipnis V. Could exposure assessment problems give us wrong answers to nutrition and cancer questions? J Natl Cancer Inst 2004;96:1564-5.

45 Kristal AR, Peters U, Potter JD. Is it time to abandon the food frequency questionnaire? Cancer Epidemiol Biomarkers Prev 2005;14:2826-8.

46 Willet W. Nutritional epidemiology. 2nd ed. Oxford University Press, 1998.

47 Kipnis V, Subar AF, Midthune D, Freedman LS, Ballard-Barbash R, Troiano RP, et al. Structure of dietary measurement error: results of the OPEN Biomarker Study. Am J Epidemiol 2003;158:14-21.

48 Prentice RL. Dietary assessment and the reliability of nutritional epidemiology reports. Lancet 2003;362:182-3.
49 Fowke JH, Chung FL, Jin F, Qi D, Cai Q, Conaway C, et al. Urinary isothiocyanate levels, brassica, and human breast cancer. Cancer Res 2003;63:3980-6.

50 Bingham S, Luben R, Welch A, Low YL, Khaw KT, Wareham NJ, et al. Associations between dietary methods and biomarkers, and between fruits and vegetables and risk of ischaemic heart disease, in the EPIC Norfolk Cohort Study. Int J Epidemiol 2008;37:978-87.

51 Bingham SA, Luben R, Welch A, Wareham N, Khaw K-T, Day N. Are imprecise methods obscuring a relation between fat and breast cancer? Lancet 2003;362:212-4

52 Williams DEM, Wareham NJ, Cox BD, Byrne CD, Hales CN, Day NE. Frequent salad vegetable consumption is associated with a reduction in the risk of diabetes mellitus. J Clin Epidemiol 1999;52:329-35.

53 Van Dam RM, Rimm EB, Willett WC, Stampfer MJ, Hu FB. Dietary patterns and risk for type 2 diabetes mellitus in US men. Ann Intern Med 2002;136:201-9.

54 Montonen J, Knekt P, Haarkanen T, Jarvinen R, Heliovaara M, Aromaa A, et al. Dietary patterns and the incidence of type 2 diabetes. Am J Epidemiol 2005;161:219-27.

55 Hodge AM, English DR, O’Dea K, Giles GG. Dietary patterns and diabetes incidence in the Melbourne collaborative cohort study. Am Epidemiol 2007;165:603-10.

56 Agte VV, Tarwadi KV, Mengale S, Chiplonkar SA. Potential of traditionally cooked green leafy vegetables as natural sources for supplementation of eight micronutrients in vegetarian diets. J Food Compost Anal 2000;13:885-91.

57 Tarwadi K, Agte V. Potential of commonly consumed green leafy vegetables for their antioxidant capacity and its linkage with the micronutrient profile. Int J Food Sci Nutr 2003;54:417-25.

58 Larsson SC, Wolk A. Magnesium intake and risk of type 2 diabetes: a meta-analysis. J Intern Med 2007;262:208-14.

59 Hulbert AJ, Turner N, Storlien LH, Else PL. Dietary fats and membrane function: implications for metabolism and disease. Biol Rev 2005;80:155-69.

60 Hu FB, van Dam RM, Lui S. Diet and risk of type II diabetes: the role of types of fat and carbohydrate. Diabetologia 2001;44:508-817.

61 Lui S, Ajani U, Chai C, Hennekens C, Buring JE, Manson JE. Long-term $\beta$-carotene supplementation and risk of type 2 diabetes mellitus. A randomized controlled trial. JAMA 1999;282:1073-5.

62 Marchioli R, Schweiger C, Levantesi G, Tavazzi L, Valagussa F. Antioxidant vitamins and prevention of cardiovascular disease: epidemiological and clinical trial data. Lipids 2001;36:53-63S

Accepted: 28 June 2010 